\title{
Biology and Thermal Requirements of Fopius arisanus (Sonan, 1932) (Hymenoptera: Braconidae) Reared on Ceratitis capitata Eggs (Wiedemann) (Diptera: Tephritidae)
}

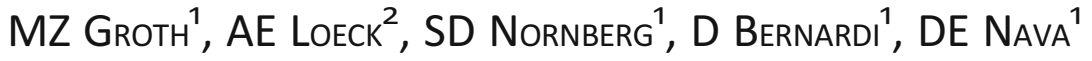 \\ ${ }^{1}$ Embrapa Clima Temperado, Lab de Entomologia, Pelotas, RS, Brasil \\ ${ }^{2}$ Faculdade de Agronomia Eliseu Maciel, Depto de Fitossanidade, Univ Federal de Pelotas, Pelotas, RS, Brasil
}

\section{Keywords}

Biological control, fruit fly, Braconidae, egg parasitoid, degree-days, development

\section{Correspondence}

DE Nava, Embrapa Clima Temperado, Lab de Entomologia, BR $392 \mathrm{Km} \mathrm{78,} \mathrm{Cx.} \mathrm{Postal:}$ 403, CEP 96010-971 Pelotas, RS, Brasil; dori. edson-nava@embrapa.br

Edited by Christian S Torres - UFRPE

Received 20 January 2017 and accepted 10 April 2017

Published online: 4 May 2017

(C) Sociedade Entomológica do Brasil 2017

\begin{abstract}
Fopius arisanus (Sonan) is a solitary parasitoid of eggs and the first instar larvae of Tephritidae. Due to the occurrence of Ceratitis capitata (Wiedemann) in various regions and under several climatic conditions, this study aimed to evaluate the effect of different temperatures on the embryonic development (egg-adult) and determine thermal requirements and the number of annual generations $F$. arisanus on eggs of $C$. capitata. In the laboratory, eggs of $C$. capitata $(24 \mathrm{~h})$ were submitted to parasitism of F. arisanus during $6 \mathrm{~h}$. Later, the eggs were placed in plastic containers $(50 \mathrm{~mL})(50 \mathrm{eggs} / \mathrm{container})$ on a layer of artificial diet and packed in chambers at temperatures $15,18,20,22,25,28,30$, and $32 \pm 1^{\circ} \mathrm{C}, \mathrm{RH} 70 \pm 10 \%$, and a photophase of $12 \mathrm{~h}$. The largest number of offspring, emergence rate, and weight of adults of $F$. arisanus were observed at $25^{\circ} \mathrm{C}$. The highest sex ratios (sr $>0.75$ ) were recorded at 15 and $18^{\circ} \mathrm{C}$, being statistically higher than the temperatures $20^{\circ} \mathrm{C}(0.65), 22^{\circ} \mathrm{C}(0.64), 25^{\circ} \mathrm{C}(0.65), 28^{\circ} \mathrm{C}(0.49)$, and $30^{\circ} \mathrm{C}$ (0.47). At $32^{\circ} \mathrm{C}$, there was no embryonic development of $F$. arisanus. The egg-adult period was inversely proportional to temperature. Based on the development of the biological cycle (egg-adult), the temperature threshold $\left(T_{\mathrm{t}}\right)$ was $10.3^{\circ} \mathrm{C}$ and thermal constant $(K)$ of 488.34 degree-days, being the number of generations/year directly proportional to the temperature increase. The data show the ability of $F$. arisanus to adapt to different thermal conditions, which is important for biological control programs of $C$. capitata.
\end{abstract}

\section{Introduction}

Fopius arisanus (Sonan, 1932) (Hymenoptera: Braconidae) is originally from Indo-Australian regions and is considered the main egg parasitoid of fruit flies species Bactrocera dorsalis (Hendel) and Ceratitis capitata (Wiedemann) (Diptera: Tephritidae) (Vargas et al 2012) with the ability to parasitize on the first instar larvae of $C$. capitata (Manoukis et al 2011, Murillo et al 2015).

Historically, in 1940, F. arisanus was introduced in Hawaii (USA) for control of $B$. dorsalis and C. capitata (Clausen et al 1965). Later, it was introduced in various regions of Australia, Central America, and the islands of the Indian and Pacific
Oceans for control and elimination of fruit flies species of the Tephritidae family (Harris et al 2007, Vargas et al 2007, Manoukis et al 2011). In Brazil, F. arisanus was introduced from insects obtained originally from Hawaii in 2012 by Embrapa (Brazilian Agricultural Research Corporation) in the municipality in Jaguariúna, São Paulo State, and by the Ministry of Agriculture, Livestock and Food Supply (MAPA) for biological control of carambola fly Bactrocera carambolae (Drew \& Hancock, 1994) (Diptera: Tephritidae) in the State of Amapá (Groth et al 2016).

Due to its capacity of parasitism and development in eggs of $C$. capitata (Harris et al 2007, Vargas et al 2007, Manoukis et al 2011, Vargas et al 2012, Groth et al 2016), F. arisanus can 
be an alternative for the management of $C$. capitata, which is considered one of the main fruit fly species in Brazil (Malavasi et al 2000, Nava and Botton 2010, Zucchi 2015), which control is carried out with chemical insecticides (e.g., phosphorous, pyrethroids, and spinosyns) (Nava and Botton 2010). Due to the factors related to its biotic potential, polyphagy, and ability to infest a variety of native and exotic hosts (Aluja and Mangan 2008), the Mediterranean fruit fly has its occurrence reported in almost all Brazilian regions throughout the year (Malavasi et al 2000, Zucchi 2015).

The high adaptability of the pest to different environmental conditions can provide to $F$. arisanus unfavorable thermal conditions for distribution, adaptation, survival, and reproduction (Damos and Savopoulou-Soultani 2012, Khaliq et al 2014). Therefore, the understanding of the relative importance of temperature and development of $F$. arisanus will help to determine models the occurrence and survival of the natural enemy in the environment (Haddad et al 1999). As well as, the knowledge of the thermal requirements of F. arisanus will provide information about its ability to develop on the $C$. capitata under different thermal conditions and help to create strategies for mass production programs aimed at biological control. In this sense, the objective of this work was to study the parasitoid potential to develop under different temperatures, determine thermal requirements, and estimate the number of offspring of $F$. arisanus reared on eggs of $C$. capitata.

\section{Material and Methods}

Rearing of C. capitata and F. arisanus

The species of $C$. capitata and $F$. arisanus were obtained from colonies rearing at the Entomology Laboratory of Embrapa Clima Temperado, Pelotas, Rio Grande do Sul, Brazil, in controlled room conditions of $25 \pm 2^{\circ} \mathrm{C}, 70 \pm 10 \%$ $\mathrm{RH}$, and a photophase of $12 \mathrm{~h}$.

For rearing and maintenance of $C$. capitata, adults were kept in plastic cages $(48 \mathrm{~cm}$ long by $30 \mathrm{~cm}$ wide and $30 \mathrm{~cm}$ tall) and fed with refined sugar, wheat germ, and yeast at ratio $3: 1: 1$, respectively, provided in a plastic Gerbox ${ }^{\mathrm{TM}}$ (11.5 cm long by $11.5 \mathrm{~cm}$ wide by $3.5 \mathrm{~cm}$ tall) (J. Prolab Ltda., São José dos Pinhais, Paraná, Brazil) and distilled water in plastic containers $(250 \mathrm{~mL}$ ) provided via capillarity with a sponge vegetable cloth (Spontex ${ }^{\mathrm{TM}}$, Ilheús, Bahia, Brazil) (Nunes et al 2013). The eggs were obtained and the aeration and inoculum processes in artificial diet were carried out according to the methodologies proposed by Kamiya (2010) and Gonçalves et al (2013). The larval development of $C$. capitata was carried out in artificial diet proposed by Salles (1992) and modified by Nunes et al (2013).
After the emergence of $F$. arisanus adults, approximately 400 females and 100 males from the sixth generation in $C$. capitata eggs reared at the laboratory were placed in plastic cages $(23 \mathrm{~cm}$ long by $27 \mathrm{~cm}$ wide and $40 \mathrm{~cm}$ tall) according to Gonçalves et al (2013). Adults were fed with a honey-based paste $(30 \%)$ and distilled water supplied via capillarity through a sponge vegetable cloth (Spontex ${ }^{\mathrm{TM}}$ ), which was replaced every 72 h. Four days after parasitoid emergence, eggs of C. capitata (apx. 2500 eggs) obtained from the lab colony were deposited on a piece of filter paper $(4 \mathrm{~cm}$ diameter) with the aid of a LabMate ${ }^{\mathrm{TM}}$ micropipette on top of a piece of sponge cloth (Spontex ${ }^{\mathrm{TM}}$ ) and placed in an acrylic plate ( $4 \mathrm{~cm}$ diameter by $0.2 \mathrm{~cm}$ tall), being offered for $6 \mathrm{~h}$ to females of F. arisanus (Groth et al 2016). Later, the eggs were removed and placed on a layer of artificial diet for larval development. After 9 days, the larvae were removed from the artificial diet with a sieve $(0.22 \mathrm{~mm})$ and running water and placed in plastic containers $(200 \mathrm{~mL})$ on a layer of extra-fine vermiculite $(3 \mathrm{~cm})$ where pupation occurred. They remained there until the parasitoids emerged to form a new generation (Groth et al 2016).

\section{Effect of temperature on the development of immature stages of $\mathrm{F}$. arisanus and determining thermal requirements}

Approximately 7500 eggs of $C$. capitata ( $24 \mathrm{~h}$ old) obtained from the lab colony were deposited on a piece of filter paper ( $4 \mathrm{~cm}$ wide) on a sponge cloth (Spontex ${ }^{\mathrm{TM}}$ ) ( $4 \mathrm{~cm}$ diameter) and placed in acrylic plates ( $4 \mathrm{~cm}$ wide by $0.2 \mathrm{~cm}$ tall) as described previously. Posteriorly, these plates were placed inside cages ( 1 plate/cage $23 \mathrm{~cm} \times 27 \mathrm{~cm} \times 40 \mathrm{~cm}$ ) containing adults of $F$. arisanus ( 300 females and 100 males) in a proportion of approximately 25-30 eggs of $C$. capitata per female (13 days old) according to peak $F$. arisanus oviposition rate (Groth et al 2016). After $6 \mathrm{~h}$ of exposure, the plates were removed and, with the aid of a fine brush, 50 eggs were randomly removed and inoculated in artificial diet $(25 \mathrm{~mL})$ in plastic pots $(50 \mathrm{~mL}$ ) for larval development, according to the diet of Salles (1992), modified by Nunes et al (2013). Subsequently, the pots were placed in a climatized room at $15,18,20,22,25,28,30$, and $32^{\circ} \mathrm{C}, \mathrm{RH} 70 \pm 10 \%$, and $\mathrm{a}$ photophase of $12 \mathrm{~h}$. After emerging, the first pupae of each treatment were removed from the artificial diet with a sieve ( $0.2 \mathrm{~mm}$ mesh) and running water and transferred to acrylic containers $(2.5 \mathrm{~cm}$ wide by $4.5 \mathrm{~cm}$ tall) containing a layer of extra-fine vermiculite $(1 \mathrm{~cm})$ to allow pupation. The pupae were checked daily for the emergence of adults to determine the egg-adult period (days). The intact puparia in which emergence of insects ( $C$. capitata or $F$. arisanus) was not observed were dissected with the aid of tweezers to check the actual parasitism rate. The biological parameters 
evaluated for each temperature (treatment) were (i) eggadult period (days); (ii) number of offspring (NO) obtained by the equation: $\mathrm{NO}=$ number of parasitoids emerged + number of parasitoids that did not emerge; (iii) emergence rate $(\mathrm{E} \%)$ determined by the equation: $\mathrm{E}(\%)=$ (number of parasitoids emerged)/(number of offspring) $\times 100$; (iv) weight of adults at $24 \mathrm{~h}$ old, and (v) sex ratio (sr) by the equation: $s r=$ (number of females)/(number of females + number of males).

\section{Statistical analysis}

The experiment was conducted in a completely randomized design with eight temperatures (treatments) with 20 replicates per temperature, being each replicate composed of 50 eggs. The data for the egg-adult period (days), NO, and $\mathrm{E}(\%)$ were submitted to the analysis of variance by the GLM procedure (PROC GLM, SAS ${ }^{\circledR}$ 9.1) (SAS Institute 2002) and the means were compared by the Tukey test at $5 \%$ significance (SAS Institute 2002). The values for sex ratio were analyzed by the chi-square test $\left(\chi^{2}\right)(P<0.05)$ (SAS Institute 2002). For number of offspring, if statistical significance occurred, temperature effects were evaluated by regression models $(P<0.05)$ represented by equations: $y=b^{2}+a x+y o$, where $y=$ variable response; $y o=$ response variable corresponding to the minimum point of the curve; $a=$ maximum estimated value for the variable response; $b=$ curve slope; and $x$ = temperature (SAS Institute 2002). The thermal requirements of the immature stages of $F$. arisanus were estimated by the hyperbola method (Haddad et al 1999), calculating the lower limit for temperature or the temperature threshold $\left(T_{\mathrm{t}}\right)$ and the thermal constant $(K)$ (SAS Institute 2002). The number of $F$. arisanus generations in eggs of $C$. capitata per year in laboratory conditions was estimated using the equation NG $=\{T(\mathrm{Tm}-\mathrm{Tb}) / K\}$ where: $K=$ thermal constant; $\mathrm{Tm}=$ average temperature; $\mathrm{Tb}=$ inferior thermal threshold, and $T=$ time in days.

\section{Results}

There was no development of $F$. arisanus at constant temperature of $32^{\circ} \mathrm{C}$, indicating that this should be the maximum tolerable limit for parasitoid development. The emergence rate of $F$. arisanus was greater at temperatures $22^{\circ} \mathrm{C}(83 \%)$ and $25^{\circ} \mathrm{C}(83 \%)$, differing significantly $\left(F_{6},{ }_{136}=88.34\right.$; $P<0.0007$ ) at the other temperatures (Table 1). The data on the total number of offspring produced by females at the studied temperatures adjusted to the quadratic polynomial regression equation $\left(F_{6},{ }_{136}=88.34 ; P<0.0007\right)$ obtained a determination coefficient $\left(R^{2}=0.88\right)$. The maximum number of offspring per female estimated by the model was 22.5 at $25^{\circ} \mathrm{C}$ (Fig 1). However, the number of females of $F$. arisanus in relation to the number of males was statistically higher $\left(\chi^{2}=263.40, \mathrm{~g} . I=6, P<0.0001\right)$ at lower temperatures $(15$ and $18^{\circ} \mathrm{C}$ ) (Table 1$)$. Adult body mass of males $\left(F_{6,154}=54.31\right.$, $P<0.0001)$ and females $\left(F_{6}, 136=53.71, P<0.0001\right)$ was higher in intermediate temperatures $\left(20,22\right.$, and $\left.25^{\circ} \mathrm{C}\right)$ (Table 1).

Average developmental time (egg-adult) of $F$. arisanus was shortened by temperature increase $\left(F_{6},{ }_{136}=316.28\right.$, $P<0.0001$ ) (Fig 2), showing that $99 \%$ of the reduction of the development time was explained by the temperature increase $\left(R^{2}=0.99\right)$ (Fig 3). According to the average duration of the egg-adult period (days) of $F$. arisanus, the lower thermal limit or temperature threshold was $10.3^{\circ} \mathrm{C}$, corresponding to a thermal constant $(K)$ of 488.34 degree-days when reared in C. capitata eggs (Fig 3). Based on these values, the number of annual generations of $F$. arisanus was estimated to range from 2.69 to 6.43 within the thermal range 15 to $30^{\circ} \mathrm{C}$ (Table 2 ).

\section{Discussion}

An important aspect to determine population dynamics of insects is based on the estimation of the optimal
Table 1 Means $( \pm \mathrm{SE}$ ) of emergence (\%), sex ratio, and weight (mg) of Fopius arisanus reared in Ceratitis capitata eggs at different temperatures.

\begin{tabular}{lllll}
\hline Temperature $\left({ }^{\circ} \mathrm{C}\right)$ & Emergence $(\%)^{\mathrm{a}}$ & Sex ratio & \multicolumn{2}{l}{ Weight $(\mathrm{mg})^{\mathrm{a}}$} \\
\cline { 4 - 5 } & & & Male & Female \\
\hline 15 & $36 \pm 5.87 \mathrm{~d}$ & $0.78 \mathrm{a}$ & $1.43 \pm 0.09 \mathrm{c}$ & $1.56 \pm 0.62 \mathrm{c}$ \\
18 & $53 \pm 4.09 \mathrm{c}$ & $0.73 \mathrm{a}$ & $2.16 \pm 0.14 \mathrm{~b}$ & $2.25 \pm 0.17 \mathrm{~b}$ \\
20 & $70 \pm 3.12 \mathrm{~b}$ & $0.65 \mathrm{~b}$ & $2.66 \pm 0.69 \mathrm{a}$ & $2.70 \pm 0.69 \mathrm{a}$ \\
22 & $85 \pm 5.10 \mathrm{a}$ & $0.64 \mathrm{~b}$ & $2.67 \pm 0.63 \mathrm{a}$ & $2.80 \pm 0.35 \mathrm{a}$ \\
25 & $83 \pm 3.12 \mathrm{a}$ & $0.63 \mathrm{~b}$ & $2.78 \pm 0.02 \mathrm{a}$ & $2.86 \pm 0.03 \mathrm{a}$ \\
28 & $57 \pm 5.98 \mathrm{c}$ & $0.49 \mathrm{c}$ & $1.98 \pm 0.04 \mathrm{~b}$ & $2.05 \pm 0.01 \mathrm{~b}$ \\
30 & $21 \pm 2.18 \mathrm{e}$ & $0.47 \mathrm{c}$ & $1.44 \pm 0.04 \mathrm{c}$ & $1.48 \pm 0.04 \mathrm{c}$ \\
\hline
\end{tabular}

${ }^{\text {a }}$ Columns followed by different letters differ by the Tukey test $(P \leq 0.05)$.

${ }^{\mathrm{b}}$ Significant difference by the chi-square test (a female-biased sex ratio). 
Fig 1 Average number of offspring per female of Fopius arisanus reared in eggs of Ceratitis capitata at different temperatures. (Vertical bars represent the confidence intervals at $95 \%)$.

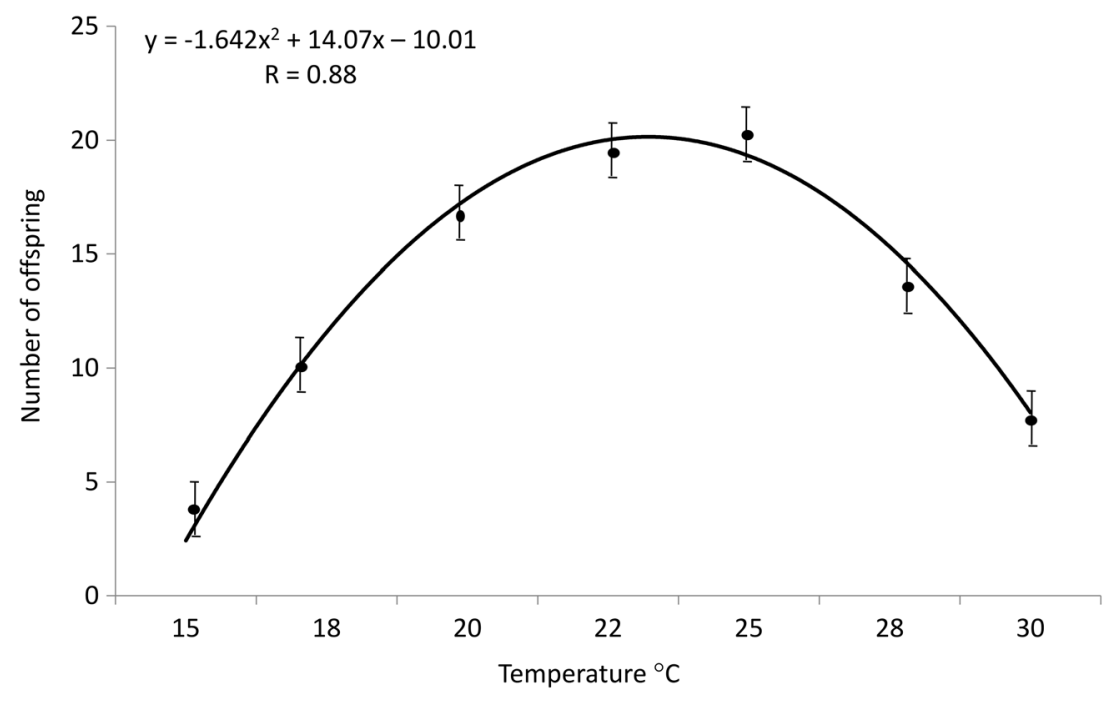

temperature for the development of the host and the natural enemy (Khaliq et al 2014). In this study, the biological characteristics of egg-adult development of $F$. arisanus on eggs of $C$. capitata were significantly influenced by temperature. Favorable thermal conditions to obtain the highest number of offspring and emergence of parasitoids were obtained at temperature $25^{\circ} \mathrm{C}$. Similar values were observed with the same species in eggs of Bactrocera invadens (Drew, Tsuruta \& White) (Diptera: Tephritidae) (Appiah et al 2013) and C. capitata (Ramadan 2004, Zenil et al 2004, Kroder and Messing 2010), as well as for parasitoids Aganaspis pelleranoi (Brèthes, 1924) (Hymenoptera: Figitidae) (Gonçalves et al
2014), Diachasmimorpha longicaudata (Ashmead, 1905) (Hymenoptera: Braconidae) (Meirelles et al 2013), and Doryctobracon brasiliensis (Szépligeti) (Hymenoptera: Braconidae) (Poncio et al 2016) in larvae of Anastrepha fraterculus (Wiedemann) (Diptera: Tephritidae).

One of the factors that contribute to the increase of parasitism and success of biological control is the presence of a larger number of females in the insect population. In this work, the largest number of females was obtained at temperatures 15 and $18^{\circ} \mathrm{C}$. In contrast, there was a reduction (sr $<0.50$ ) at temperatures above $28^{\circ} \mathrm{C}$, showing that temperature variation affects the ratio between the sexes
Fig 2 Duration of egg-adult development of Fopius arisanus in eggs of Ceratitis capitata at different temperatures. Columns followed by different letters differ by the Tukey test $(P \leq 0.05)$.

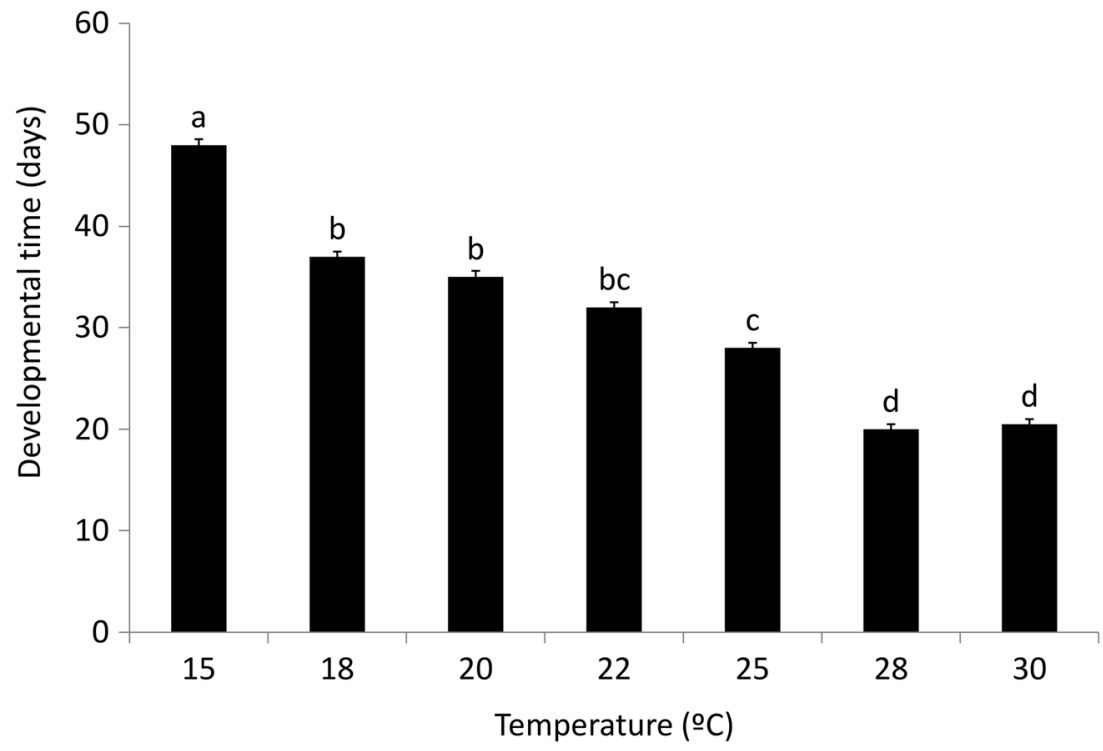


Fig 3 Curve of development rate of the egg-adult period of Fopius arisanus reared in eggs of Ceratitis capitata at different temperatures.

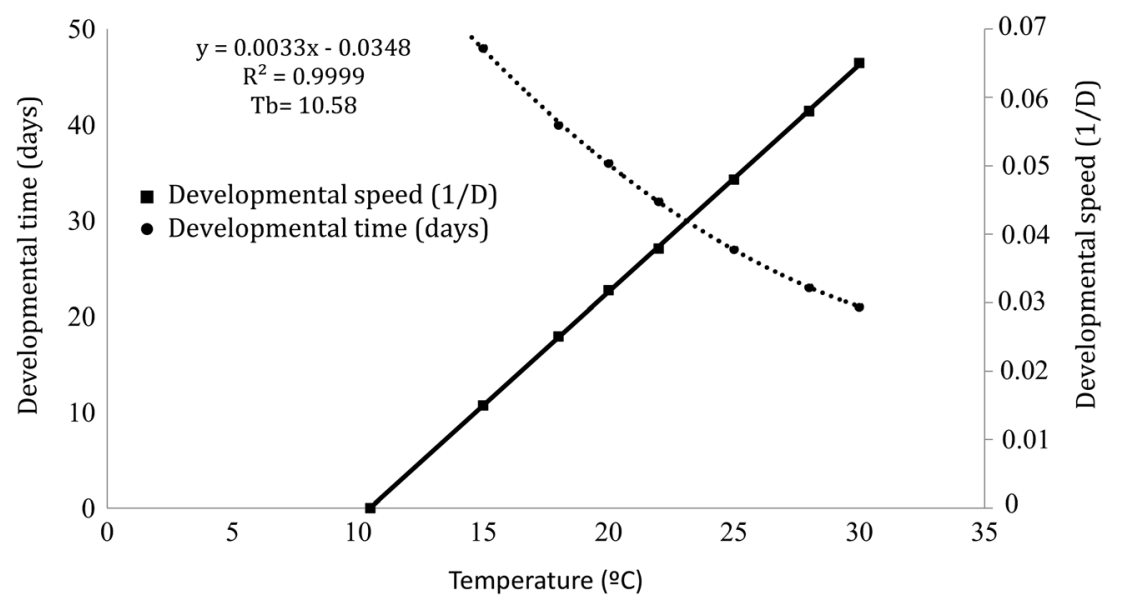

The adequate temperature range $\left(22-25^{\circ} \mathrm{C}\right)$ to the embryonic development of $F$. arisanus observed in this study was equivalent to the optimum temperature for development and survival of $C$. capitata (Ricalde et al 2011). Similar developmental times between $F$. arisanus and $C$. capitata under the same thermal conditions (temperatures 22 and $25^{\circ} \mathrm{C}$ ) can provide positive effects on the increase population dynamics of parasitoids in field conditions (Rwomushana et al 2008). The co-occurrence between parasitoids and hosts, associated with preference for parasitism of egg and the first larvae of $C$. capitata offers $F$. arisanus greater host foraging resources (Vargas et al 2012, Montoya et al 2009) offers F. arisanus greater foraging in the search for the host, increasing the chances of parasitism and suppression of the pest (Rousse et al 2009).

The egg-adult development time of $F$. arisanus was inversely proportional within the temperature range of 18 $30^{\circ} \mathrm{C}$. Constant extreme temperatures $\left(15-32^{\circ} \mathrm{C}\right)$ were harmful to this parasitoid. This was possible due to the fact that F. arisanus was not adapted to these conditions. In general, extreme constant temperatures $\left(15\right.$ and $\left.32^{\circ} \mathrm{C}\right)$ were detrimental to the embryonic development of $F$. arisanus, as observed for Diachasmimorpha tryoni (Cameron) (Hymenoptera: Braconidae) (Hurtrel et al 2001), D. longicaudata (Meirelles et al 2013), A. pelleranoi (Gonçalves et al 2014), and D. brasiliensis (Poncio et al 2016). However, in the field, the insect can survive under these thermal conditions, as extreme temperatures for extended periods are rare and usually occur during the day (Haddad et al 1999). This factor, along with the preimaginal development of the parasitoid inside the fruit, 
provides insect protection from extreme temperatures and ideal conditions for survival, as observed in hot regions of Hawaii (USA) in B. dorsalis and C. capitata (Wong et al 1992, Bokonon-Ganta et al 2007, Appiah et al 2013).

Although the number of generations per year of $F$. arisanus was calculated based on thermal requirements $\left(T_{\mathrm{t}}\right.$ and $\left.K\right)$ observed in the laboratory. This information allows us to make inferences for different locations and climatic conditions, given that $C$. capitata has its occurrence reported in practically all Brazilian regions (Malavasi et al 2000, Zucchi 2015). However, it is possible that in some regions of southern Brazil, F. arisanus presents difficulties surviving the winter (June to August) due to the low temperatures and mainly because of the reduction of $C$. capitata in the field during this time of the year (Kovaleski et al 2000). The occurrence with the South American fruit fly A. fraterculus in southern Brazil (Malavasi et al 2000, Nava and Botton 2010, Zucchi 2015), along with the parasitism capacity of $F$. arisanus in species of the genus Anastrepha (Bautista et al 2004, Zenil et al 2004, Montoya et al 2009, Groth et al 2016), in this host helps meet the needs in the absence of preferred host and facilitates its stay in the field (Groth et al 2016). Although more studies are needed to verify the adaptability of the parasitoid to field conditions, the observations in this study provide important information to design strategies for future releases and implementations of biological control programs in C. capitata at regional scale.

Acknowledgments The authors are grateful to the National Council for the Improvement of Higher Education (CAPES) for granting a scholarship to the first author.

\section{References}

Aluja M, Mangan RL (2008) Fruit fly (Diptera: Tephritidae) host status determination: critical conceptual, methodological, and regulatory considerations. Annu Rev Entomol 53:473-502

Appiah EF, Ekesi S, Salifu D, Afreh-Nuamah K, Obeng-Ofori D, Khamis F, Mohamed SA (2013) Effect of temperature on immature development and longevity of two introduced opiine parasitoids on Bactrocera invadens. J Appl Entomol 137:571-579

Bautista RC, Harris EJ, Vargas RI, Jang EB (2004) Parasitization of melon fly (Diptera: Tephritidae) by Fopius arisanus and Psyttalia fletcheri (Hymenoptera: Braconidae) and the effect of fruit substrates on host preference by parasitoids. Biol Control 30:156-164

Bokonon-Ganta AH, Ramadan MM, Messing RH (2007) Reproductive biology of Fopius ceratitivorus (Hymenoptera: Braconidae), an egglarval parasitoid of the Mediterranean fruit fly, Ceratitis capitata (Diptera: Tephritidae). Biol Control 41:361-367

Cancino J, Villalobos P, De La Torres S (2002) Changes in the rearing process to improve the quality of mass production of the fruit parasitoid Diachasmimorpha longicaudata (Ashmead) (Hymenoptera: Braconidae). In: Proceeding of 7 th workshop of the global IOBC
Working Group: quality control of mass reared arthropods. Ed. By Leppla NV, Bloem KA, Luck RF, Rimmi, Italy, 74-82

Clausen CP, Clancy DW, Chock QC (1965) Biological control of the oriental fruti fly (Dacus dorsalis Hendel) and other fruit flies in Hawaii. Washington, USDA, ARS, 102p. (Technical Bulletin 1322)

Damos P, Savopoulou-Soultani M (2012) Temperature-driven models for insect development and vital thermal requirements. Psyche 2012: Article 123405

Gonçalves RS, Nava DE, Pereira HC, Lisbôa H, Grutzmacher AD, Valgas RA (2013) Biology and fertility life table of Aganaspis pelleranoi (Hymenoptera: Figitidae) in larvae of Anastrepha fraterculus and Ceratitis capitata (Diptera: Tephritidae). Ann Entomol Soc Am 106: 791-798

Gonçalves RS, Nava DE, Andreazza F, Lisbôa H, Nunes AM, Grutzmacher $A D$, Valgas RA, Maia AHN, Pazianotto RAA (2014) Effect of constant temperatures on the biology, life table, and thermal requirements of Aganaspis pelleranoi (Hymenoptera: Figitidae), a parasitoid of Anastrepha fraterculus (Diptera: Tephritidae). Environ Entomol 43: 491-500

Groth MZ, Loeck AE, Nornberg SD, Bernardi D, Nava DE (2016) Biology of Fopius arisanus (Hymenoptera: Braconidae) in two species of fruit flies. J Insect Sci 16:1-7

Haddad ML, Parra JRP, Moraes RCB (1999) Métodos para estimar os limites térmicos inferior e superior de desenvolvimento de insetos. Piracicaba, FEALQ, 29p

Harris EJ, Bautista RC, Vargas RI, Jang EB (2007) Rearing Fopius arisanus (Sonan) (Hymenoptera: Braconidae) in mediterranean fruit fly (Diptera: Tephritidae). Hawaii Entomol Soc 39:121-126

Hurtrel B, Quilici S, Nenon JP, Lelannic J (2001) Pre-imaginal developmental biology of Diachasmimorpha tryoni (Cameron): a parasitoid of the Mediterranean fruit fly. Insect Science and its Application 21:81-88

Kamiya AC (2010) Criação massal em dieta líquida e radioesterilização da mosca-sul-americana Anastrepha sp. 1 aff. fraterculus (Wied., 1830) (Diptera: Tephritidae), p. 71. Dissertação (Mestrado) - Centro de Energia Nuclear para a Agricultura. Universidade de São Paulo, Piracicaba

Khaliq A, Javed M, Sohail M, Muhamand S (2014) Environmental effects on insects and their population dynamics. J Entomol Zool Stud 2:1-7

Kovaleski A, Sugayama RL, Uramoto K, Malavasi A (2000) Moscas-dasfrutas nos Estados Brasileiros: Rio Grande do Sul, p. 285-290. In: Malavasi A, Zucchi RA (eds) Moscas-das-frutas de importância econômica no Brasil (conhecimento básico e aplicado). FAPESPHolos, Ribeirão Preto, $327 \mathrm{p}$

Kroder S, Messing RH (2010) A new parasitoid from Kenya, Fopius ceratitivorus, complements the extant parasitoid guild attacking Mediterranean fruit fly in Hawaii. Biol Control 53:223-229

Malavasi A, Zucchi RA, Sugayama RL (2000) Biogeografia, pp. 93-98. In Malavasi A, and Zucchi RA (eds), Moscas-das-frutas de importância econômica no Brasil: conhecimento básico e aplicado. Ribeirão Preto, Holos Editora, $327 \mathrm{p}$

Manoukis N, Geib S, Seo D, Mckenney M, Vargas R, Jang E (2011) An optimized protocol for rearing Fopius arisanus, a parasitoid of tephritid fruit flies. J Vis Exp 53:1-4

Meirelles RF, Redaelli LR, Ourique SB (2013) Comparative biology of Diachasmimorpha longicaudata (Hymenoptera: Braconidae) reared on Anastrepha fraterculus and Ceratitis capitata (Diptera: Tephritidae). Fla Entomol 96:412-418

Montoya P, Suárez A, López F, Cancino J (2009) Fopius arisanus oviposition in four Anastrepha fruit fly species of economic importance in Mexico. Biol Control 54:437-444

Murillo FD, Cabrera-Mireles H, Barrera JF, Liedo P, Montoya P (2015) Doryctobracon areolatus (Hymenoptera: Braconidae) a parasitoid of early developmental stages of Anastrepha obliqua (Diptera: Tephritidae). J Hymenopt Res 46:91-105

Nava DE, Botton M (2010) Bioecologia e controle de Anastrepha fraterculus e Ceratitis capitata em pessegueiro. Embrapa Clima 
Temperado, Pelotas, RS. 29p. (Embrapa Clima Temperado. Documentos, 315)

Nunes AM, Nava DE, Muller FA, Gonçalves RS, Garcia MS (2011) Biology and parasitic potential of Doryctobracon areolatus on Anastrepha fraterculus larvae. Pesq Agropec Bras 46:669-671

Nunes AM, Costa KZ, Faggioni KM, Costa MLZ, Gonçalves RS, Walder JMM, Garcia MS, Nava DE (2013) Dietas artificiais para a criação de larvas e adultos da mosca-das-frutas sul-americana. Pesq Agropec Bras 48:1309-1314

Poncio S, Nunes AM, Gonçalves RS, Lisboa H, Manica-Berto R, Garcia MS, Nava DE (2016) Biology of Doryctobracon brasiliensis at different temperatures: development of life table and determining thermal requirements. J Appl Entomol 140:775-785

Ramadan MM (2004) Mass-rearing biology of Fopius vandenboschi (Hymenoptera: Braconidae). J Appl Entomol 128:226-232

Ricalde MP, Nava DE, Loeck AE, Donatti MG (2011) Temperaturedependent development and survival of Brazilian populations of the Mediterranean fruit fly, Ceratitis capitata, from tropical, subtropical and temperate regions. J Insect Sci 12:1-9

Rousse P, Harris EJ, Quilici S (2005) Fopius arisanus, an egg pupal parasitoid of Tephritidae overview. Biocontrol News and Informations 26: 59-69

Rousse P, Gourdon F, Roubaud M, Chiroleu F, Quilici S (2009) Biotic and abiotic factors affecting the flight activity of Fopius arisanus, an egg-pupal parasitoid of fruit fly pests. Environ Entomol 38:896-903

Rwomushana I, Ekesi S, Gordon I, Ogol CK (2008) Host plants and host plant preference studies for Bactrocera invadens (Diptera:
Tephritidae) in Kenya, a new invasive fruit fly species in Africa. Ann Entomol Soc Am 101:331-340

Salles LAB (1992) Metodologia de criação de Anastrepha fraterculus (Wiedmann, 1830) (Diptera: Tephritidae) em dieta artificial em laboratório. Ann Soc Entomol Brasil 21:479-486

Sas Institute (2002) Statistical analysis system: getting 476 started with the SAS learning. SAS 477 Institute, Cary, NC

Vargas RI, Leblanc L, Putoa R, Eitam A (2007) Impact of introduction of Bactrocera dorsalis (Diptera: Tephritidae) and classical biological control releases of Fopius arisanus (Hymenoptera: Braconidae) on economically important fruit flies in French Polynesia. J Econ Entomol 100:670-679

Vargas RI, Leblanc L, Putoa R, Pinero JC (2012) Population dynamics of three Bactrocera spp. fruit flies (Diptera: Tephritidae) and two introduced natural enemies, Fopius arisanus (Sonan) and Diachasmimorpha longicaudata (Ashmead) (Hymenoptera: Braconidae), after an invasion by Bactrocera dorsalis (Hendel) in Tahiti. Biol Control 60:199-206

Wong TTY, Ramadan MM, Herr JC, McInnis DO (1992) Suppression of a Mediterranean fruit fly (Diptera: Tephritidae) population with concurrent parasitoid and sterile fly release in Kula, Maui, Hawaii. J Econ Entomol 85:1671-1681

Zenil M, Liedo P, Williams T, Valle J, Cancino J, Montoya P (2004) Reproductive biology of Fopius arisanus (Hymenoptera: Braconidae) on Ceratitis capitata and Anastrepha spp. (Diptera: Tephritidae). Biol Control 29:169-178

Zucchi RA (2015) Mosca-do-mediterrâneo, Colocar em italico (Diptera: Tephritidae). In: Vilela EF, Zucchi RA (ed) Pragas Introduzidas no Brasil: Insetos e Ácaros. São Paulo: FEALQ, Cap.1 